\title{
USING PRODUCTION INPUT AND PRODUCTIVITY OF LOCAL SHALLOT WITH THE IMPLEMENTATION OF GOOD AGRICULTURE PRACTICES IN DONGGALA, INDONESIA
}

\author{
Christoporus C. ${ }^{1,2 *}$, Mustabjad M.M. ${ }^{3}$, Hanani N. ${ }^{3}$, Syafrial S. ${ }^{3}$ \\ ${ }^{1}$ Faculty of Agriculture, University of Brawijaya, Indonesia \\ ${ }^{2}$ Agricultural Economics Department, University of Tadulako, Indonesia \\ ${ }^{3}$ Agricultural Economics Department, University of Brawijaya, Indonesia \\ *E-mail: christoporus70@yahoo.com
}

\begin{abstract}
The area of study is Tanantovea; a region located in Donggala Regency, Indonesia, towards 97 farmers participated in Good Agriculture Program (GAP) for local shallot agriculture that has met the Standard Operating Procedure (SOP) and 62 farmers who do not participate in the program. The purpose of the study is analyze the implementation of GAP towards production input between the farmers who participate in GAP and those who do not, and analyze partial productivity and Total Factor of Productivity (TFP) between the farmers who participate in GAP and those who do not. The t-test analyzes the production input shows that it is significant when $\alpha 1 \%$ two-tail test with probability rate of $0.000<0.01$; these indicate that there is different implementation of GAP towards production input between the farmers who participate in GAP and those who do not. The implementation of production input by GAP participants is higher than those the non-participants in that the participants are able to produce is $81.78 \%$ of seeds, $66.67 \%$ of organic fertilizer, $79.46 \%$ of inorganic fertilizer and $77.76 \%$ of pesticide. The amount of labor force by the GAP participants is $89.70 \mathrm{HOK}$ or lower than the amount of labor force by non-participants that is $107.56 \mathrm{HOK}$. The t-test analyzing partial productivity shows that it is significant when $\alpha 10 \%$ in two-tailed test with probability rate of $0.052<0.10$. These indicate there is different partial productivity between the farmers who participate in GAP and those who do not. The partial productivity of GAP participants is 6,289.25 kilograms per hectare and that of non-participants is 6,019.35 kilograms per hectare. For TFP, probability rate is $0.089<0.10$ and the level of significance is $90 \%$ in two-tailed testing. These show significant difference in terms of TFP between the farmers who participate in GAP and those who do not. The average TFP of the GAP participants is 1.0076 kilogram per hectare and that of non-participant is 0.9622 kilograms per hectare.
\end{abstract}

\section{KEY WORDS}

Good Agriculture Practicess (GAP), production input, productivity.

The goal of development of the agricultural sector in Indonesia is to provide food and employment opportunities. It also has contribution as non-oil foreign exchange. Construction and development of the agricultural sector in Central Sulawesi, especially in rural areas by taking geographic location into account is an alternative to poverty alleviation and increase income of farmers, more particularly on local products as specific agricultural commodities (Purmiyanti, 2002). 23,221 hectares of dry land, great variety of local shallots and supportive growing requirements are the elements that can develop local shallot as the leading agricultural commodity. Local shallot productivity at the farmer's level is between 3 and 5 tons per hectare; the number is way less than its potential production that is 11.10 tons per hectare. The common obstacle in shallot cultivation is the use of well-selected (Maemunah, 2010) and inappropriate use of fertilizer (Jayathilake, et al., 2006). Therefore, technology related to production in farming is vital especially one that increases both production and productivity of the local shallot.

Production technology or production possibility set is implemented in one unit of production in order to select input-output configuration $(x, y) \in T$ as production plan (Fried, 
et.al, 1993). Technology that is used in shallot cultivation in Donggala is Good Agriculture Practicess (GAP).

GAP is a type of technology or cultivation that use good and appropriate methods of cultivation during production so that it meets the SOP in order to produce well-qualified and edible products as the reference. GAP is developed due to commitment and attention towards production and food security, food security and quality of food as well as sustainable farming (Asparianto, 2008).

The implementation of GAP in the local shallot agriculture is directed to business development and enhance the competitive advantage of the commodity which leads to increasing productivity and business efficiency in the utilization of agricultural resources as well as increasing the quality of human resources (Tamrin, et al ., 2002 ). Furthermore Baharuddin, et.al , (2003), and Rahim, et.al (2012) concluded that using technology to modify the environment where the local shallot is grown results in 5.49 tons to 10.48 tons per hectare of productivity.

Based on the elaboration, the purpose of the study is (1) analyze the implementation of GAP towards production input between the farmers who participate in GAP and those who do not, and (2) analyze partial productivity and Total Factor of Productivity (TFP) between the farmers who participate in GAP and those who do not.

\section{METHODOLOGY OF RESEARCH}

The study was conducted in 2014 Tanantovea, a region in Donggala Regency, Indonesia, that becomes the center of local shallot cultivation and most farmers in the area have implemented GAP. The sampling method is Simple Random Sampling towards 212 farmers who participate in GAP and 135 farmers who do not participate in GAP program using Parel et al (1973)'s formula as follow:

$$
n=\frac{N Z^{2} \sigma^{2}}{N d^{2}+Z^{2} \sigma^{2}}
$$

Where:

$\mathrm{n}=$ number of samples;

$\mathrm{N}=$ population of farmers who participate in GAP and farmers who do not participate in GAP; $z=$ normal variable in the expected level of significance $(95 \%)=1.96$;

$\sigma=$ population variance $(0.19)$ of farmers who participate in GAP and farmers who do not participate in GAP;

$d=$ standar of error (0.05).

The population variance is obtained using the following formula:

$$
\sigma^{2}=\frac{\sum_{i=1}^{\mathrm{N}}\left(X_{i}-\mu\right)^{2}}{\mathrm{~N}}
$$

Where:

$\mathrm{X}=$ score of each observation;

$\mu=$ average population of shallot farmers in Guntarano and Wombo village;

$\mathrm{N}=$ population of farmers who participate in GAP and farmers who do not participate in GAP.

Therefore, number of samples is proportionally determined using the following formula:

$$
\mathrm{n}_{\mathrm{b}}=\left(\mathrm{N}_{\mathrm{b}} / \mathrm{N}\right)^{*} \mathrm{n}
$$

Where:

$\mathrm{n}_{b}=$ number of samples of farmers who participate in GAP and farmers who do not participate in GAP;

$\mathrm{N}_{\mathrm{b}}=$ population of farmers who participate in GAP and farmers who do not participate in GAP; 
$\mathrm{N}=$ total population of farmers (347 farmers who consist of 212 farmers as GAP participants and 135 farmers as non-participants);

$\mathrm{n}=$ total samples of farmers who participate in GAP and farmers who do not participate in GAP.

Therefore, from both villages, the samples are 97 farmers who participate in GAP program and 62 farmers who do not participate in the program.

The first purpose of the study is achieved by finding out scoring using several production inputs namely seeds, organic fertilizer, inorganic fertilizer and pesticide. The scoring is obtained by comparing the scores of the farmers who participate in GAP and farmers who do not participate in GAP using the following formula:

$$
\text { Level of Implementation }=\frac{\text { Total score of } X i \text { input being used }}{\text { Maximum Xi score }} x \mathbf{1 0 0} \%
$$

Production input score is in the form of percentage (\%) while working day input is in the form of Hari Orang Kerja (HOK), the number of working days.

The following procedure is how to conduct independent t-test (Walpole, 1993) in order to compare how much seeds, organic and organic fertilizer as well as pesticide are used and how many hours of labor needed between farmers who participate in GAP and farmers who do not.

In order to find out level of local shallot cultivation productivity, the researcher used two methods, partial method (production of shallots per one hectare of land) and total factor of productivity using transitive TFP index. Analyzing TFP of the land aims at analyzing how much shallots every one hectare of land in the cultivation can produce, while TFP aims at analyzing the ability of all production factors being used to produce output. Productivity is used to compare physical performance of various local shallot cultivations located in different regions and physical performance between local shallot farmers who participate in GAP programs and the local shallot farmers who do not participate in GAP program.

a) Partial productivity (production per local shallot cultivation) between farmers participating in GAP program and farmers not participating in the program.

$$
\text { Productivity }=\frac{\text { Output }}{\text { Cultivation Area }}
$$

To compare partial productivity between farmers who participate in GAP and farmers who do not participate in GAP, independent t-test (Walpole, 1993) with the following hypotheses is conducted. The hypotheses are as follow:

$\mathrm{H}_{0}: \mu_{1}=\mu_{2}$ (there is no difference in partial productivity between farmers who participate in GAP programs and those who do not participate in the program in local shallot cultivation located in Donggala).

$\mathrm{H}_{1}: \mu_{1} \neq \mu_{2}$ (there is no difference in partial productivity between farmers who participate in GAP programs and those who do not participate in the program in local shallot cultivation located in Donggala).

Where:

$\mu_{1}=$ average partial production from population of local shallot farmers who become GAP participants.

$\mu_{2}=$ average partial production from population of local shallot farmers who do not become GAP participants.

The data are analyzed using SPSS version 18.00 program where hypothesis testing criteria are as followed:

1. If probability $(p)<0.10, \mathrm{H}_{0}$ is rejected;

2. If probability $(p) \geq 0.10, H_{0}$ is accepted. 
b) In order to compare TFP (total factor of productivity), Fisher index is used together with TFPIP Version 1.0 program.

The formula used to measure the Fisher index (Coelli, 1998 is as followed:

$$
\begin{gathered}
\text { TFP } P_{s t}=\frac{\text { IndexOutpu } t_{s t}(\text { Fisher })}{\text { IndexInput }{ }_{s t}(\text { Fisher })} \\
\text { IndexOutput }_{s t}(\text { Fisher })=Q_{s t}^{F}(\text { Index Output Quality })=\sqrt{Q_{s t}^{L} x Q_{s t}^{P}} \\
Q_{s t}^{L}=\frac{\sum_{i=1}^{N} p_{i s} q_{i t}}{\sum_{i=1}^{N} p_{i s} q_{i s}}, Q_{s t}^{P}=\frac{\sum_{i=1}^{N} p_{i t} q_{i t}}{\sum_{i=1}^{N} p_{i t} q_{i s}}
\end{gathered}
$$

Where:

$Q_{s t}^{F}=$ Index Output Quantity (Fisher)

$Q_{s t}^{L}=$ Index Output Quantity (Laspeyres)

$Q_{s t}^{P}=$ Index Output Quantity (Pasche)

$p_{i}=\mathrm{i}^{\text {th }}$ output price

$q_{i}=$ number of $\mathrm{i}^{\text {th }}$ output

I = total output $(i=1, \ldots, N)$

$\mathrm{S}=$ Farmers as GAP participants

$\mathrm{t}=$ Farmers as non GAP participants

$$
\begin{aligned}
& \text { IndexInput }(\text { Fisher })=Q_{s t}^{F}(\text { IndexInput Quantity })=\sqrt{Q_{s t}^{L} x Q_{s t}^{P}}, \\
& Q_{s t}^{L}=\frac{\sum_{i=1}^{N} p_{i s} q_{i t}}{\sum_{i=1}^{N} p_{i s} q_{i s}}, Q_{s t}^{P}=\frac{\sum_{i=1}^{N} p_{i t} q_{i t}}{\sum_{i=1}^{N} p_{i t} q_{i s}}
\end{aligned}
$$

Where:

$Q_{s t}^{F}=$ Index Output Quantity (Fisher);

$Q_{s t}^{L}=$ Index Output Quantity (Laspeyres);

$Q_{s t}^{P}=$ Index Output Quantity (Pasche);

$p_{i}=\mathrm{i}^{\text {th }}$ output price;

$q_{i}=$ number of $\mathrm{i}^{\text {th }}$ output;

I = total output $(i=1, . ., N)$;

$\mathrm{S}=$ Farmers as GAP participants;

$\mathrm{t}=$ Farmers as non GAP participants.

\section{RESULTS AND DISCUSSION}

In order to answer the first statement of the problems, comparative analysis of local shallot cultivation production input between the farmers who participate in GAP and those who do not participate in GAP is conducted. The result of the comparative analysis is presented in Table 1. 
Table 1 - Local Shallot Cultivation Input between Farmers who participate in GAP Programs and Farmers who do not Participate in GAP Program, 2014

\begin{tabular}{lll}
\hline Input & Farmers as GAP Participants & Farmers as non GAP Participants \\
\hline Seeds (\%) ${ }^{* * *}$ & 81.78 & 67.74 \\
Organic Fertilizer (\%) $^{* * *}$ & 66.67 & 56.45 \\
Inorganic Fertilizer (\%) ${ }^{* * *}$ & 79.46 & 69.09 \\
Pesticide (\%) ${ }^{* * *}$ & 77.76 & 74.14 \\
Man Labour (HOK) ${ }^{*}$ & 89.70 & 107.56 \\
\hline
\end{tabular}

Source :Primary Data, 2014.

Notes: *** level of significance when $\alpha 1 \%,{ }^{* *}$ level of significance when $\alpha 5 \%$, *level of significance when $\alpha 10 \%$.

Seeds. The findings show that, use of seeds by the farmers who participate in GAP program is $81.78 \%$. It is categorized as high use of seeds since the average use of seeds is 838.47 kilograms per hectare while the use of seeds by the farmers who do not participate in GAP is $67.74 \%$. It is categorized as mild since the average use of seeds is 910.36 kilograms per hectare. There is a possibility to use more seeds until $900-1,000$ kilograms per hectare as suggested by Department of Agriculture of Central Sulawesi. The farmers who participate in GAP program generally used certified seeds while the farmers who do not participate in GAP program use either certified seeds, seeds from the previous harvest or ones they bought at the local markets of which quality is still questionable. These happen because the price of seeds is high at the farmer's level (Maemunah, 2010). Besides using uncertified seeds, the farmers also increase the gap between plants; such condition will affect production and productivity (Alam, et al, 2012). It is in line with Handri, et.al (2013) that certified seeds have significant and positive influence towards diameter of the shallots, how hard the shallot is, production and productivity. Using medium size seeds with small gap between plants will minimize the use of seeds and therefore, cost of production (Darma, et al., 2015). Sumiati, et.al (2014) conclude that using large size seeds will influence growth of plants and result in taller plants.

Organic Fertilizer. Percentage of organic fertilizer the GAP participants use is $67.67 \%$ and the percentage of organic fertilizer the non GAP participants use is $56.45 \%$; these percentages are categorized as mild use of organic fertilizer. The average use of organic fertilizer by GAP participants is 1.25 tons/ha and that by non GAP fertilizer is 1.10 tons/ha. Both groups of farmers are allowed to use more organic fertilizer since the recommended use of organic fertilizer is 10 tons per hectare. The two farmer groups use goat manure produced by the local farmer's group as the organic fertilizer. It is in line with Asrul (2009) who stated that the advantages of organic fertilizer are it fertilizes surface of the soil, increases absorption and storage of water as well as increases number of microorganism that improves soil fertility. In addition, organic fertilizer enhances physical, chemical and biological characteristics of the soil (Simanungkalit, et.al, 2006). Limbongan and Monde (2002) conclude that 1.20 tons of organic fertilizer will result in 5.64 tons of dehydrated local shallots per hectare.

Inorganic Fertilizer. Percentage of inorganic fertilizer the GAP participants use is $79.46 \%$ or can be categorized as high. The inorganic fertilizers the farmers use include 158.93 kilograms of urea per hectare, 140.36 kilograms of $\mathrm{KCl}$ fertilizer per hectare and 158.93 kilograms of SP-36 fertilizer per hectare. On the other hand, percentage of inorganic fertilizer the non GAP participants use is $69.09 \%$ or can be categorized as mild. The inorganic fertilizers the farmers use include 185.93 kilograms of urea per hectare, 74.67 kilograms of $\mathrm{KCl}$ fertilizer per hectare and 152.59 kilograms of SP-36 fertilizer per hectare. Both groups of farmers can use more inorganic fertilizer because the recommended use of Urea is $100-200$ kilograms/ha, $\mathrm{KCl}$ is $100-200$ kilograms/ha and SP-36 is 150-300 kilograms/ha. It is in line with Shaheen, et al. (2007), Aisha, et al. (2007), Shafeek, et al. (2013), and El-Bassiony (2006) who conclude that addition of N,P, and K will increase weight and diameter of Giza 20, a variety of shallot and the productivity is 13.91 tons per hektar.

The farmers use small percentage of organic fertilizer because small amount of inorganic fertilizer can fulfill their need. Inorganic fertilizer is practical and increases 
production. The farmers combine organic and inorganic fertilizers. It is in line with Asrul (2009) and Azis, et al, (2011) who conclude that inorganic fertilizer is practical and has one or more components that increases production and structure of the soil.

Pesticides. Percentage of pesticide the GAP participants use is $77.76 \%$ (high use of pesticide) while the non GAP participants use $74.14 \%$ of pesticide (high use of pesticide). The pesticide is given twice, 20 and 40 days after the shallots are planted to anticipate pest and disease. It is given more often during cloudy or rainy season because during the time shallot is more vulnerable to pests and diseases.

It is in line with Sahara and Indrus, (2004) who state that pesticide has significant influence towards rice production in Indonesia. However, Khazanani and Nugroho (2011) mention that excessive use of pesticide do not have significant influence towards chili production in Temanggung-Indonesia.

Man Labour. Based on the findings of the study, the amount of man labor by GAP participants is $89.70 \mathrm{HOK}$ while the amount of man labor by non GAP participants is 107.56 HOK. Most of the man labor done by non GAP participants involves controlling weeds, pests and disease. The labors are paid daily or based on piece-work system. It is in line with Siska (2014) who conclude that the type of work where labors are paid with the piece-work system is pulling out paddy. Furthermore, Trimulyantara and Hendriadi (2004) state that the amount of man labor for production farmers for one hectare of land is 893 hours while farmers who incorporate agricultural technology require 665.50 hours for one hectare of land. On the other hand, cattle breeders in Grobongan who employ family members as labors has higher income compared to using non-family members as workers (Handayani, et.al, 2005).

The following procedure is to describe partial productivity towards TFP. The findings of the study towards partial productivity show that the probability rate is $0.052<0.10$ in twotailed test that means significance between partial productivity of the GAP participants whose average production is $6,289.25$ kilograms per hectare and that of the non-GAP participants whose average production is 6,019.35 kilogram per hectare. These indicate that GAP increase production of the farmers who apply the program. It is in line with Onduru, et.al (2012) who mention that farmers who participate in SLPTT GAP for tea plantation in Kenya can increase production to 1,297 kilograms per hectare compared to farmers who do not participate in the program whose production is 1,121 kilograms per hectare from the previous year. Probability rate of TFP is $0.089<0.10$ in two-tailed test that shows significance between average TFP of the GAP participants, 1.0076 kilograms per hectare and average TFP of non GAP participants, 0.9622 kilograms per hectare.

It is in line with Vu, et al., (2011) that manure, Indian lilac seed, Azotobacter and worm casting result in maximal production of $\mathrm{N}-2-4-1$, a variety of shallot as well as increase soil fertility more effectively compared to NPK fertilizer. The use of chicken manure, pig manure, green manure and fertilizer from industrial waste improve quality of roots of Agrifound Dark Red, a variety of shallot and its ability to absorb more nutrient (Simanungkalit, et al, 2006).

\section{CONCLUSION}

The implementation of GAP in the local shallot cultivation towards production input indicates that the farmers who participate in GAP programs have been able to use efficient production input so that it has positive impacts towards increasing production of the local shallots. Partial productivity and Total Factor of Productivity (TFP) of the GAP participants are higher than those of non GAP participants. The average partial productivity of the GAP participants is $6,289.25$ kilograms per hectare while that of the non GAP participants is $6,019.35$ kilograms per hectare. The average TPF of the GAP participants is 1.0076 kilograms per hectare while the average TFP of the non GAP participants is 0.9622 kilograms per hectare. These indicate that the farmers who participate in GAP program have been able to carry out the implementation of GAP for the local shallot cultivation management. 


\section{REFERENCES}

1. Aisha, A.H., Rizk, F.A., Shaheen, A.M., and Abdel-Mauty, M.M. 2007. Onion Plant Growth, Bulbs Yield and its Physical and Chemical Pproperties as Affected by Organic and Natural Fertilization. Res. J agric \& Bilo. Sci, 3 (5), page: 380-383

2. Asrul. 2009. Apa Keunggulan Pupuk Organic Dibanding Anorganik. http:// ahoesein.blogspot.com/2009/08/apa-keunggulan-pupuk-organik-dibanding.

3. Aspariyanto T.S. 2008. Panduan Good Agriculture Practicess (GAP) Tanaman Sayuran, Dinas Pertanian, Kehutanan dan Kelautan Kota Palu.

4. Azis, M.A., A.T. Aezum., S.S. Mahdi, and T. Ali. 2012. Effect of Integrated Nutrient Management on Soil Physical Properties Using Soybean (Glycine Max (L) Merill) as Indicator Crop under Temperate Conditions. International Journal of Current Research, 4 (1), page ; $203-207$.

5. Baharudin, S., Wardiyati, T., and Santoso, M. 2003. Modifikasi Lingkungan Untuk Meningkatkan Hasil bawang Merah Lokal Palu. http://www.scrib.com/doc/29609629/Modifikasi-Mulsa-Bawang-Merah.

6. Darma, W.A., Susila, A.D., and Dinarti, D. 2015. Pertumbuhan Dan Hasil Bawang Merah Asal Umbi TSS Varietas TukTuk Pada Ukuran Dan Jarak Tanam Yang Berbeda. Jurnal Agrovigor, 8 (2), page: 1-7.

7. El-Bassiony, A.M. 2006. Effect of Potassium Fertilization on Growth, Yield and Quality of Onion Plant. Journal of Applied Sciences Research, 2 (10), page:780-785

8. Fried, H., Lovell, K., and Schmidt, S. 2007. The Measurement of Productive Efficiency and Productivity. Oxford University Press, the Red Book.

9. Handayani. M., Gayatri. S., and Mulyatno, B.S. 2005. Pendapatan Tenaga Kerja Keluarga Pada Usaha Ternak Sapi Potong Di Kecamatan Toroh Kabupaten Grobogan. Mediargo, 1 (2), page : 38-44

10. Jayathilake, P.K.S., Reddy, I.P., Srihari, D., and Reddy, K.R. 2006. Productivity And Soil Fertility Status As Influenced By Integrated Use Of N-Fixing Biofertilizers, Organic Manures And Inorganic Fertilizers In Onion. The Journal of Agricultural Sciences, 2 (1)., page : 46-58.

11. Khazanani, A. and Nugroho. 2011. Analisis Efisiensi Penggunaan Faktor-Faktor Produksi Usahatani Cabai Kabupaten Temanggung. Retrieved from http://www.google.co.id/\#sclient=psy-ab \& q = Khazanani\% 2C + A.\% 2C ++ Dan + Nugroho\% 2C + 2.011 on 11 June 2013.

12. Limbongan, J. and Monde, A. 2000. Pengaruh Pemberian Pupuk Organik dan Anorganik Terhadap Pertumbuhan dan Produksi Bawang Merah Lokal Palu. J. Hort, 9 (3), page 212 -219 .

13. Maemunah. 2010. Viabilitas dan Vigor Benih Bawang Merah Pada Berbagai Varietas Penyimpanan. Jurnal Agroland, 17(1), Page :18-22.

14. Nur, A., Istiati, and Muhardi. 2012. Optimalisasi Peningkatan Mutu dan Daya Saing Poduk Unggulan Bawang Merah Lokal Palu. Laporan Hasil Penelitian Sttagis Nasional Tahun I. Lembaga Penelitian Universitas Tadulako Palu, page 57-62.

15. Onduru, D.D., De Jager, A., Hiller, S., Van den Bosch, R. 2012. Sustainability of Smallholder Tea Production in Developing Countries: Learning Experiences From Farmer Field Schools in Kenya. International Journal of Development and Sustainability, 1 (3), page : 714-742.

16. Parel, C.P., Caldito, G.C., Ferrer, G.C., De Guzman, G.G., Sisioco, G.G., and Tan, R.H. 1973. Sampling Design and Prosedures. The Ahric. Development Council Inc. New York.

17. Purmiyanti, S. 2002. Analisis Produksi dan Daya Saing Bawang Merah Di Kabupaten Brebes Jawa Tengah. Unpublished Thesi, Institut Pertanian Bogor.

18. Rahim, A., Baja, S., Mustafa, M., and Ibrahim B., 2012. Daya Adaptasi dan Potensi Bawang Merah Varietas Lokal Palu. http://pasca.unhas.ac.id/jurnal/files.

19. Sahara, D., and Idris, (2005). Efisiensi Produksi Sistem Usaha Tani Padi Pada Lahan Sawah Irigasi Teknis. Http://www.ejournal.unud.ac.id. 
20. Shafeek, M.R., Nagwa., M.K. Hassa., S.M. Singer, and N.H.M. EL-Greadly, 2013. Effect of Potassium Fertilizer and Foliar Spraying With Etherel on Plant Development, Yield and Bulb Quality of Onion Plant (Allium cepa L). Journal of Applied Sciences Research, 9 (2), page:1140-1146.

21. Shaheen, A.M., Abdel-Mouty, M.M., Ali, A.H., and Rizk, F. 2007. Natural and Chemical Phosphorus Fertilizers as Affected Onion Plant Growth, Bulbs Yield and its Some Physical and Chemical Properties. Aust. J. Basic \& Appl. Sci, 1 (4), page: 519-524.

22. Simanungkalit, R.D,M., Suriadikarta, D.A., Saraswati, R., Setyorini, D., and Hartatik, W. 2006. Pupuk Organik dan Pupuk Hayati. Balai Besar litbang Sumberdaya Lahan dan Pertanian Badan Penelitian dan Pengembangan Pertanian Bogor, page: 265-271.

23. Sumiati, E., Sumarni, N and Hidayat (2004). Perbaikan Teknologi Produksi Umbi Benih Bawang Merah Dengan Ukuran Umbi Benih, Aplikasi ZPT dan Unsur Hara Mikroelement. J.Hort, 14 (1), page :25-32.

24. Tamrin, Ramlan, M., Ruchjaningsih, A., and Wahdania. 2002. Pengkajian Sistem Usahatani Bawang Merah di Sulawesi Selatan. Jurnal Pengkajian dan Pengembangan Teknologi Pertanian, 6(3).

25. Trimulyantara, L and Hendriadi, A. 2004. Optimalisasi Pengunaan Energi Pada Budidaya Pasang Surut. Studi kasus Di Banyuasin Sumatera Selatan. Proseding. Seniminar Nasional Pengembangan Lahan Rawa dan Pengendalian Pencemaran Lingkungan, page: $147-153$

26. Vu, T.K., Patil, H.M., and Gudedhe, N.N. 2011. Effect of Integrated Nutrient Management on Onion Yield and Soil Properties in Soybean - Onion Croppng Sequence. Omonrice (18), page: $112-120$. 